\title{
Rethinking Political Wellbeing in Representational Democracy in Japan
}

\author{
Yoshiaki Kobayashi $^{1}$ D . Sangjoon $\mathrm{Kim}^{2}$
}

Received: 18 December 2019 / Accepted: 26 April 2021

(c) The Author(s) 2021

\begin{abstract}
This study discusses how representational democracy is related to the issues of community wellbeing in that political promises are contested in process of election campaigns. Under the premises that many promises largely reflect issue of community wellbeing, we seek to enhance understanding of how styles of representative democracy impact community wellbeing by comparing aspects of single-member (SMD) and multimember districts (MMD) in the Japan case.

Among the questions considered: (1) Do voters' choices increase in SMD compared to MMD systems? (2) Does issue voting increase in SMD? (3) Do SMD systems expand policy debate? and, (4) Does the voters' will determine the policies of elected representatives? We measure each of these variables, related to mechanisms for electing representatives, with an assumption that wellbeing is closely related to voters' participation and satisfaction. Based on our analysis, we conclude that SMD is not better than MMD at promoting these aspects of community wellbeing.
\end{abstract}

Keywords Democracy $\cdot$ Electoral system $\cdot$ SMD $\cdot$ MMD

\section{Wellbeing and "For the People" Democracy}

Today, there is a strong need of conducting a new line of research whose focus is lied on the correlation between the specific types of political practices and the general level of people's satisfaction they feel about their community. Since most of the current political regimes, though with different degree, tend to converge on democracy, the type of political practices examined in this paper comes from the realm of democratic regime, especially from Japanese condition.

Yoshiaki Kobayashi

kobayashi@z5.keio.jp

1 Keio University, Tokyo, Japan

2 Yonsei University, Seoul, Republic of Korea 
The beginning of this argument is derived from the significant change in understanding the core values of democracy. Democracy used to mean "Rule by Majority". While this principle worked as a foundation for a variety of practices such as "Separation of Power", "Periodic Election", and "Rule of Law", this kind of understanding democracy only through the technical perspective turned out to be less than satisfactory. Today, there is a growing consensus that the true values of democracy lie in the fact that democracy can increase the general wellbeing of the people.

Since democracy allows all members of society to actively participate in the decision-making process, people can make their voice heard more vividly and have more opportunities to convince others to appreciate their ideas and thoughts under the relatively safer condition. This shows that the core values of democracy have been gradually shifted from the "formality of rule by majority" to the actual contents of the community allegedly under the democratic regime. This grandeur shift can be understood as a general tendency of moving from the classical version of "By the People Democracy" to more resent form of "For the People Democracy" when it comes to assessing how much successful the given democratic regime has been. To put it another way, it is, nowadays, not enough to observe the principle of people's sovereignty only in the form of election - "By the People Democracy" - to be called a legitimate and successful democracy. What is more important is to assure the full realization of people's sovereignty - "For the People Democracy" - by making sure that they not only have a right to choose their representatives, but also hold a power to influence the actual contents of laws and rules of their communities to which they belong. Democracy with lack of sovereignty in the hands of people would not be considered a rightful form of democracy at all.

Likewise, the conventional understanding that any forms of democracy can improve the wellbeing turns out to be inappropriate. As it is mentioned above, "By the People Democracy" which is largely based only on the principle of "Rule by Majority" can always go into the wrong direction, exterminating its virtues of improving wellbeing through its specialized practices.

This paper analyses a type of democracy we termed "For the People" Democracy to deepen the understanding of promoting community-wellbeing. Studies have considered what constitutes wellbeing and how it could be improved. Various social, economic, political, cultural, physical, and environmental conditions have been recognized as statistically important variables for influencing community-wellbeing as a whole, and for each member. Among these diverse factors, social and economic variables have been considered "key conditions" for improved wellbeing because they are directly related to the community's resources and willingness to employ them to advance collective and individual wellbeing.

Political variance has also been examined. Conditions of political equality and freedom, resulting from national struggles, are now well known to constitute individual wellbeing, but the previous approaches have not paid a due attention to the relation between the types of community and the level of wellbeing. This led to the asymmetrical findings in which the importance of equality and freedom for wellbeing is readily observable, while the process connecting democratic governing practices and wellbeing still remains opaque. 
In this respect, we consider the impact of alternative democratic processes on wellbeing by quantitatively comparing aspects of single-member (SMD) and multimember districts (MMD) in the case of Japan. Among the questions considered: (1) Do voters' choices increase in SMD compared to MMD systems? (2) Does issue voting increase in SMD? (3) Do SMD systems expand policy debate? and, (4) Does the voters' will determine the policies of elected representatives? We measure each of these variables, related to mechanisms for electing representatives, with an assumption that wellbeing is closely related to voters' participation and satisfaction. Based on our analysis, we conclude that SMD is not better than MMD at promoting these aspects of community wellbeing.

\section{"For the People" Democracy}

Democratic systems vary from country to county in the mode of representation. The diversity largely stems from several distinctive features: (1) different power relationships between voters and elected representatives, (2) different roles for representatives, (3) different ways of utilizing election systems, and (4) different mechanisms for choosing representatives. Across these dimensions, contrasting elements compete with each other (Lijphart, 2012).

1. In terms of the power relationship between voters and elected representatives in a democratic system, voters are regarded as principals while representatives are regarded as agents. In the agent-centered model, agents act mostly independent of principals in determining the principals' conditions. On the other hand, in the principal-centered model, principals control the agent and, thus, more completely their conditions.

2. In terms of their representing roles, elected representatives are considered delegators or trustees. As a delegator, elected representatives are more likely to convey the will of voters while, as a body of trustees, elected representors are more likely to pursue their own political will or agendas.

3. In terms of voters utilizing the election system, the election process could be used as arena for communication or empowering among voters. In this situation, election process turns out to be a communication. In the communication model, voters tend to use elections to express their opinions, views, and rights. In the empowerment model, voters tend to use the election to maximize their political power through their candidates winning the election. In this case, election process turns out to be a power game.

4. In terms of mechanisms for choosing elected representors, two models are considered. A Westminster model where candidates are elected in single-member districts (SMDs), with the preferences of the minority of voters not reflected in the outcome, and (2) and a consensus-type model using proportional representation (PR) to elect candidates according to the percentage of the total vote that their parties secure, thereby better incorporating the preferences of all voters. 
In reality, the above features are not separated but integrated. The principalcentered model is closely related to the delegators model while the agent-centered model to the trustee model. The principal-centered or delegators model opens more chances in the election process for voters' communication, while the agent-centered or trustee model is used for maximizing political power.

Finally, hypothetically, these variations are closely connected with the Westminster model or consensus-type model of elections. The consensus-type model is more likely to be coterminous with the principal-centered, delegators system- a communication-centered model. Westminster model is aligned with an agent-centered, trustee system —an empower-centered model (Table 1).

\section{Wellbeing and Electoral Systems}

Because "wellbeing" is a subjective concept, we need to explain how the above features of representative democracy differently impact it. In a political sense, wellbeing could be enhanced in the following situation. When voters' choices increase, they pay more attention to issues and the policy debate expands, so that voters are more likely to participate in a Habermasian public discourse that encourages their individual engagement and enhances the prospects for compromise on major policy issues. Ideally, this engaged electorate is more informed, accepting of electoral and policy outcomes, and respectful of other views, and less apathetic, biased, and adversarial. (Chappell, 2012) Improved engagement and discourse enlarges the community's ability to determine what is considered a "just" society and how best to promote community values. (Sandel, 2008) Voters are more likely to engage in a Rawlsian exercise of political rights, including free speech and assembly, better securing the foundations of liberal democracy(See, 2002).

Possibly, these properties of political wellbeing are more likely to be achieved in situations of (1) principal-centered rather than agent-centered, (2) elected representatives as delegators rather than as trustees, and (3) electoral systems that enhance voters' communication. Then, we may assume that the consensus-type model with proportional representation provides a better condition for increasing wellbeing than the single-member district model since the former is closely related to these three situations.

We need to incorporate another aspect of representative democracy-the realization of political promises (manifesto). If the above situation is an input process of representative democracy which increase wellbeing by maximizing voters'

Table 1: A heuristic comparison of electoral types

Consensus-type model vs. Westminster model

\begin{tabular}{llll}
\hline principal-centered & $\leftarrow$ & $\rightarrow$ & agent-centered \\
elected representatives as delegators & $\leftarrow$ & $\rightarrow$ & elected representatives as trustees \\
election for voters' communication & $\leftarrow$ & $\rightarrow$ & election for voters' empowerment \\
\hline
\end{tabular}


satisfaction, we may also think about an output process of an election. Wellbeing increases when political promises (manifesto) are realized. In the input process, wellbeing increases because voters enjoy freer, more engaged political conditions in elections. In the output process, wellbeing increases because voters eventually gain their desired social, economic, and political conditions. This paper measures the input (election) and output (policy) of representative democracy by using concept of wellbeing, focusing Japan.

Out of this context, the following sections of empirical analysis can be understood as an attempt to illuminate the connection between specific forms and contents of democracy (in sum, democratic practices) and the general level of satisfaction felt by the citizens. The following hypotheses deal with the four closely interconnected issues.

The first issue - voters' choices - is important to consider because the election, now thought to be a primary way of expressing people's political voices, is undoubtedly one of the core practices in modern democracy. All people are eligible for voting when they reach a certain age in democratic society, and a few other practices are better than election as a practically influential way for ordinary people to participate in politics. Thus, it is crucial for people to feel that the election is not "rigged" or "manipulated" by the powerful from the top. The importance of the first issue comes from the fact that when people have more choices based on genuine differences between candidates in elections, their concern about "rigged election" can be significantly alleviated.

The second issue - "issue attitude voting" - is also important in the same logic. Policy debates are crucial in democratic competition without which any political regime allegedly called "democracy" means nothing more than a mendacious decoration of its illiberal essence. More policy debates people have, more issues of what they believe important can be reflected in the enactment of laws and rules, and in the gradual process of structural change in their society.

The third issue - the will of the people - is precisely concerned about how much of what people truly desire and pursue are being reflected in the realm of actual politics, whose importance is already introduced briefly by the second issue.

The fourth and the final issue-the correlation between votes and subsidies - takes into consideration the problem of "votes-for-subsidies exchange system". This chronic nuisance within the democratic regime has been causing a number of problems such as "the exacerbation of identity politics", "strengthening the sense of animosity against elected officials", "the prevalence of lobbyists in politics" and "the growing division between civilians".

Therefore, it is in our interest to see if the following electoral practices in Japan have encouraged the first three issues while reducing the last one, because the intensity of each factor is closely related to the prosperity of "For the People Democracy" which is linked to the political wellbeing of people, and ultimately, to their general wellbeing as well. 


\section{Measuring Japan's Political Wellbeing: before and after 1993 election reform}

\section{Research Model}

In Japan, a system of voting in multi-member districts, with single non-transferable votes, was used for Lower House elections before electoral reform in the 1990s. This can be regarded as a quasi-consensus model of democracy with some PR elements. In contrast, the post-reform system, which primarily uses SMDs but also elects candidates in regional PR "blocks," can be viewed as a Westminster model of democracy. PR blocks consisted of 11 blocks, and a total of 176 members are elected. Write the name of the political party on the ballot. The number of winners will be allocated to each political party according to the number of votes. Though a majority of seats in this "parallel" system are won through SMDs, there are several candidates who lose in SMDs but are subsequently elected in PR blocks because "dual candidacy" allows their parallel inclusion in party lists. Candidates, who lose in SMDs but secure Diet seats in PR blocks, work toward winning in SMDs the next Lower House election, ensuring that SMDs occupy greater importance relative to PR blocks.

Lower House elections have been held on several occasions since 1996 using this post-reform, parallel system. Critics of the new system argue that it has not produced improvements. While supporters contend that there have not yet been enough elections for evaluation, twenty years have elapsed since the parallel system's introduction, permitting conclusions about its impact (Kobayashi, 2012). We empirically test whether Japan's reformed representative democracy performs superior, inferior, or equivalent to the prior system. This contributes to understanding whether voters are more engaged in Japanese elections and, thus, whether community wellbeing is better enhanced.

Previous research measured external indicators such as the proportion of votes or seats won by the ruling party (or parties) versus opposition parties. However, even if the proportion of votes or seats won by a ruling party is large, it is difficult to discern whether this was the result of widespread voter satisfaction with the ruling party or because objections to the status quo are essentially being nullified. Instead, we create new measures that focus on the functional aspects of representative democracy. We test whether a false narrative has developed that the SMD system is superior. ${ }^{1}$

In the analysis, short-term variables such as economic fluctuations, political scandals, and financial crisis were not included in the analysis as control variables. Because this analysis focuses on the structural effects of the system on voting behavior, these control variables cannot exclude the possibility of distorting the structural effects of the system.

\footnotetext{
${ }^{1}$ For analysis up to the 2005 Lower House elections, see Kobayashi, Yoshiaki. Japanese Democracy after Political Reform. Bokutakusha, 2008.
} 
Hypotheses We examine whether arguments presented by proponents of the SMD system, when the parallel system was introduced, were valid. We divide our investigation into two parts, one focused on the SMD system's purported benefits and another on the negative aspects of an MMD system that SMD allegedly would reduce.

One benefit that advocates of the SMD system asserted was its supposed ability to generate "policy debate" in electoral districts, which raises the question of what precisely is needed for this type of debate to occur. The development of a policy debate requires that several conditions be satisfied. First, there must be differences among the policies of candidates running in an SMD. Proponents stressed the idea that since multiple candidates from the same party compete in MMDs, in a single non-transferable vote system, their policies are the same and no policy debate ensues, with candidates instead competing for the support of voters by making promises only about the government services and other forms of largesse they can deliver to them. This means that for policy debate to occur, the gaps among different candidates' policies should grow. This assertion requires testing of the following hypothesis.

Hypothesis I: After shifting to an SMD system, voters' choices are not expanding.

If the outcomes of elections in SMD systems are in fact decided more by policy debates than is true in MMD systems, it is most important that voters in SMD systems actually be voting based on their attitudes toward the issues driving those debates. Issue voting in Lower House elections using an SMD system should be increasing. This expectation necessitates the testing of the following hypothesis.

Hypothesis II: After shifting to an SMD system, "issue attitude voting" is not increasing.

Proponents expected, not only that policy debates would develop after implementation, but that the people's will, as mandated by voters via the policy debate at the time of the election, would determine actual policies. This expectation, too, requires testing of the following hypothesis.

Hypothesis III: After shifting to an SMD system, the will of the people as mandated at the time of the election is not being reflected in actual policies.

SMD system proponents also emphasized that the policy debate it fostered would eliminate the need for candidates to compete based on promised services to voters. In addition, since candidates in SMDs must secure a comparatively larger share of votes to win elections than candidates in MMDs, the "votesfor-subsidies exchange system" prevalent in MMD systems whereby votes are traded for subsidies that benefit only a limited number of voters was supposed to fade away. Further, the elimination of the votes-for-subsidies exchange system in Lower House elections should have eliminated similar problems in 
House of Councillors (Upper House) and local government elections. Based on the view that such expectations were not met, it is necessary to test the following hypothesis.

Hypothesis IV: After shifting to an SMD system, the correlation between votes and subsidies has not disappeared.

\section{Analysis}

\section{Testing Hypothesis I}

We first sought to determine whether the shift from an MMD to an SMD system generated the type of policy debates anticipated when it was implemented. Hypothesis I: "After shifting to an SMD system, voters' choices are not expanding." Before conducting an analysis using survey data, we considered the policy positions of candidates in the SMD system using a multidimensional model of spatial competition for elections developed by scholars (Hinich \& Ordeshook, 1970).

The multidimensional spatial competition models posit that so long as candidates want to win in an SMD system (needless to say, most candidates run in elections trying to win), their policies converge on the mode of voters' optimal preferences. ${ }^{2}$ In other words, in the SMD system, the policies of candidates in each electoral district become similar, meaning that voters' choices are limited and no policy debate occurs. Obviously, candidates running in electoral districts do not think only of winning and act rationally to achieve that goal. But at the very least, it is clear that the possibility of policy debate becomes less in an SMD system than in an MMD system. Given this, the SMD advantage system claimed by its proponents at the time of the parallel system's introduction is logically incorrect so long as candidates seek to win elections.

Next, we tried to determine whether the trends anticipated by this rational model have developed by examining how voters subjectively perceive the policies of each party and calculating the "subjective policy gap" between the ruling party and the main opposition party. ${ }^{3}$ This policy gap will widen the voters' choices on the pluralistic level and expand the political utility of the voters (Dahl \& Tufte, 1973).

\footnotetext{
${ }^{2}$ Hinichi. M. J., \& Ordeshook, PC (1970).

${ }^{3}$ Data used for election analyses are as follows-1993 Lower House elections: JES II first wave survey (pre-survey) data and second wave survey (post-survey) data; 1996 Lower House elections: JES II sixth wave survey (pre-survey) data and the seventh wave survey (post survey); 2000 Lower House elections: Yoshiaki Kobayashi survey (pre-survey) data; 2003 Lower House elections: JES III fourth wave survey (pre-survey) data and fifth wave survey (post survey) data. The JES II was based on the "Nationwide Longitudinal Survey Study on Voting Behavior" (Ikuo Kabashima, Ichiro Miyake, Joji Watanuki, Yoshiaki Kobayashi, and Kenichi Ikeda) conducted with a grant for specially promoted research from the Ministry of Education, Culture, Sports, Science and Technology (MEXT) from 1993 to 1997. The JES III was based on the "Nationwide Longitudinal Survey Study on Voting Behavior in the Early 21st Century" (Kenichi Ikeda, Yoshiaki Kobayashi, Hiroshi Hirano) conducted with a grant for specially promoted research from MEXT from 2001 to 2005.
} 
Basically, this is a factor that can promote wellbeing from the standpoint of voters. Table 2 shows that the subjective policy gap noted between the policies of the Liberal Democratic Party (LDP) and the main opposition party was smaller during Lower House elections held under the SMD system than during 1993 Lower House elections under the MMD system, which in turn resulted in voters' choices narrowing rather than expanding. These facts appear to validate Hypothesis I.

Elections are not, of course, always held with the same candidate or policies in play, making it difficult to compare policy gaps in different elections ${ }^{4}$ At the very least, however, these results do not show the expansion of voters' choices that the parallel system was intended to engender when introduced. In addition, it is likely that analyses using survey data do not show a convergence on the mode of voters' optimal preferences expected by the rational model because the number of strong

Table 2 "subjective policy gap" between the ruling party (LDP) and the main opposition party

\begin{tabular}{|c|c|c|c|c|c|c|c|}
\hline & 1993 & 1996 & 2000 & 2003 & 2005 & 2009 & 2012 \\
\hline All Voters & 1.568 & 1.225 & 1.180 & 1.248 & 1.736 & 0.975 & 0.904 \\
\hline LDP supporter & 1.569 & 1.266 & 1.286 & 1.289 & 1.812 & 1.016 & 0.997 \\
\hline DPJ supporter & - & 1.327 & 1.791 & 1.631 & 1.970 & 0.944 & 1.013 \\
\hline Komeito (Clean Government Party) supporter & 1.571 & - & 1.157 & 1.190 & 1.706 & 1.158 & 0.767 \\
\hline SDP supporter & - & 1.360 & 1.538 & 1.265 & 1.694 & 0.984 & 0.987 \\
\hline JCP supporter & 1.789 & 0.719 & 1.315 & 1.105 & 1.210 & 1.037 & 0.775 \\
\hline New Conservative Party supporter & - & - & 0.500 & 0.944 & - & - & - \\
\hline Liberal Party supporter & - & - & 1.829 & - & - & - & - \\
\hline Social Democratic Party of Japan supporter & 1.873 & - & - & - & - & - & - \\
\hline Democratic Socialist Party supporter & 1.410 & - & - & - & - & - & - \\
\hline Socialist Democratic Federation supporter & 1.789 & - & - & - & - & - & - \\
\hline Japan Renewal Party supporter & 1.923 & - & - & - & - & - & - \\
\hline New Party Sakigake supporter & 1.750 & - & - & - & - & - & - \\
\hline Japan New Party supporter & 1.735 & - & - & - & - & - & - \\
\hline New Frontier Party (Shinshinto) supporter & - & 1.873 & - & - & - & - & - \\
\hline People's New Party supporter & - & - & - & - & - & 1.081 & 0.889 \\
\hline Reform Club (Kaikaku Club) supporter & - & - & - & - & - & 0.444 & - \\
\hline New Party Daichi supporter & - & - & - & - & - & 0.571 & 0.944 \\
\hline Your Party (Minna no to) supporter & - & - & - & - & - & 0.722 & 0.874 \\
\hline New Renaissance Party (Shinto Kaikaku) supporter & - & - & - & - & - & - & 0.861 \\
\hline Tomorrow Party of Japan supporter & - & - & - & - & - & - & 0.771 \\
\hline Japan Restoration Party supporter & - & - & - & - & - & - & 0.838 \\
\hline Independent (Nonpartisan) & 1.270 & 0.951 & 0.909 & 1.060 & 1.465 & 0.916 & 0.808 \\
\hline
\end{tabular}

\footnotetext{
4 The JESII survey covered the five key issues in the 1993 Lower House elections: "liberalization of agricultural imports," "the role of the government," "international relations," "political reform," and "the political situation" as well as the four key issues in the 1996 Lower House elections: "the consumption tax," "the role of the government," "international relations," and "constitutional amendment." The Kobayashi survey covered the three key issues in the 2000 Lower House elections: "the role of the government," "economic policy," and "constitutional amendment," and the JES III survey covered the six key issues in the 2003 Lower House elections: "the role of the government," "economic policy," "constitutional amendment," "the relationship between the central government and local governments," "international relations," and "official visit to Yasukuni Shrine." The scaling of policy positions in each survey was standardized and recalculated. Main opposition parties in different elections are as follows-1993 Lower House elections: Social Democratic Party of Japan; 1996 Lower House elections: New Frontier Party; 2000 and 2003 Lower House elections: Democratic Party of Japan.
} 
candidates has not yet narrowed to only two and/or the scope of policies featured in individual party platforms is limited.

\section{Testing Hypothesis II (a)}

We next tested Hypothesis II: "After shifting to an SMD system, "issue attitude voting" is not increasing." For this analysis, we tested the hypothesis through an examination both of voters' subjective consciousness and the correlation between candidates' campaign promises and election results.

We first conducted an analysis using the same JES II through JES V surveys, which were nationwide consciousness surveys conducted during the 11 national elections (six for the Lower House and five for the Upper House), beginning with the 1996 Lower House elections, which were the first held using the parallel system combining SMDs and PR blocks, and ending with the 2013 Upper House elections. Some explanatory variables differ across these surveys; and, regarding issue attitudes, some survey questions were asked in every survey, while others were added as needed given that different issues were often in play in different elections. However, aside from the effects of party realignment, the axes for the external criteria precipitated by Hayashi's quantification theory class II are similar and sufficiently comparable.

The results of our analysis indicate that, in general, party support is a significant independent variable predicting voting behavior, followed by cabinet support (Table 3). Moreover, the influence of party support is, as a whole, stronger in Upper House than in Lower House elections. This is probably because Upper House electoral districts, whose boundaries are those of individual prefectures, are larger in size than SMDs for the Lower House, which makes the psychological distance between candidates and voters greater and the influence of candidates' party affiliations on voter behavior stronger.

Moreover, a prominent feature of the 2012 Lower House elections was that party support was a greater explanatory independent variable than in Lower House elections in 2005 and 2009. In the 2005 Lower House elections, many unaffiliated voters voted for the LDP; and, in 2009 Lower House elections, unaffiliated voters and some LDP supporters voted for the DPJ. However, in 2012 Lower House elections, when the DPJ lost control of government, many LDP supporters (72.5\%) voted for the LDP, and many DPJ supporters $(64.0 \%)$ voted for the DPJ ${ }^{5}$ with the latter outcome perhaps due to weak DPJ supporters moving into the unaffiliated voter camp or shifting their support to some other party by the time of the election, thus producing a smaller but more dedicated DPJ support base. In addition, in the same 2012 elections, a considerable proportion of unaffiliated voters did not vote, and unaffiliated voters who did cast votes supported the LDP or the DPJ in percentages $(22.7 \%$ and $14.7 \%$, respectively) that did not deviate significantly from those in the 2009 election.

\footnotetext{
5 According to the first wave survey of Japanese Electoral Study V (JESV) by the Voting Behavior Study Group (https://jesproject.wixsite.com/jesproject).
} 
Table 3 Factors determining voting behavior: Quantification Theory II (Range)

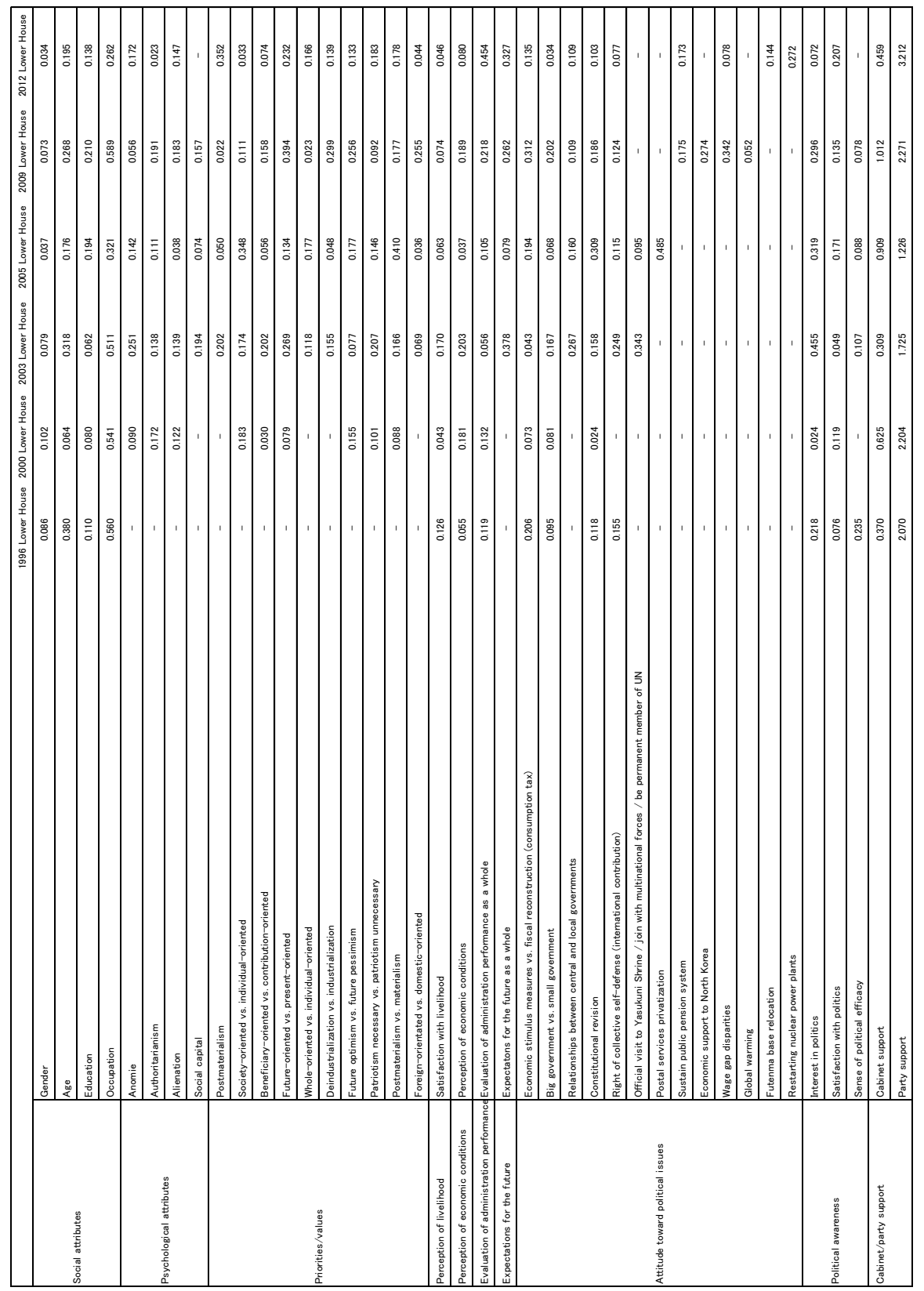

Cabinet support was a smaller independent variable in the 2012 Lower House elections than in the 2009 elections because support for the Noda Cabinet at election time in 2012 was not as weak as support for the Aso Cabinet in 2009. In contrast, 
voters evaluated the DPJ harshly, with an average "feeling thermometer" score of 37.0 degrees on a $0-100$ scale.

The 2009 Lower House elections, in which the DPJ took power, was the third election in the postwar period that yielded a change of government. The first such change produced the Katayama Cabinet, which lasted nine and a half months; and, even when adding the subsequent Ashida Cabinet, this period lasted less than a year and five months. The second such change produced the Hosokawa Cabinet, which lasted eight and a half months, and even when adding the subsequent Hata Cabinet, this period was short-lived, lasting a just over 10 months. In contrast, the DPJ administration established in 2009 lasted three years and three months through three cabinets (i.e., Hatoyama, Kan, and Noda), making it the first full-fledged change of government since the Second World War. In the 2012 Lower House Elections, half of the voters $(50.7 \%)$ answered that they either "strongly approved" or "approved" of the change of government in $2009,{ }^{6}$ greatly exceeding the $28.1 \%$ who responded that they either "did not approve" or "did not approve at all." However, when asked whether Japanese politics had improved as a result of the 2009 change of government, only $10.9 \%$ of respondents answered that it had either "improved a lot" or "somewhat improved," and a majority (56.5\%) held a negative view that it had become "much worse" or "somewhat worse." When responses to these two questions are viewed together, it appears that there was approval for the change of government itself but not for the DPJ administration.

First, in the 1996 Lower House elections, people with higher educational levels and older favorably evaluated the administration's performance due to a high degree of satisfaction with their lives, which produced votes for the ruling party via cabinet support. Approval of the administration's performance, together with satisfaction with politics formed through such factors as age, also led to support for the ruling party, and it is also possible to discern a path connecting performance approval to voting behavior directly or indirectly via support for the cabinet. In the next Lower House elections in 2000, the cabinet support rate slumped due to factors such as then-Prime Minister Yoshiro Mori's remarks about Japan being "the land of deities." Aside from older voters, support for the ruling party declined either directly, or indirectly via a lower performance rating, and a path can be seen connecting to voting behavior either directly, or indirectly via cabinet support. A path can be seen by which low administration performance approval leads to voting behavior via weaker support for the cabinet.

In the 2003 Lower House elections, people satisfied with their lives were connected to a favorable administration performance evaluation and expectations for the future through their evaluations of economic conditions. It is possible to discern a path whereby performance evaluation connected to voting behavior via political party support and cabinet support, and a path to voting behavior from expectations for the future via cabinet support. In addition, in the 2005 Lower House elections, the last such elections for the Koizumi administration, the older the individual the higher his/her evaluation of administration performance and expectations for the future through his/her satisfaction with life, with these factors leading to voting behavior in a path similar to that

\footnotetext{
${ }^{6}$ According to the second wave survey of Japanese Electoral Study V (JESV) by the Voting Behavior Study Group (https://jesproject.wixsite.com/jesproject).
} 
in the 2003 Lower House elections. Another notable feature of the 2005 Lower House elections was that "postal reform," which focused on the pros and cons of postal system privatization, connected to voting behavior via cabinet support. These are a few examples of when attitudes towards issues, however indirectly, influenced voting behavior.

Lower House elections in 2009, in which the DPJ took control of the government, took place after the fall 2008 global financial crisis and during a period when, the lower a voters' educational level, the higher his/her degree of anomie and the lower his/her level of satisfaction with life. A low level of satisfaction with life led, via a poor evaluation of economic conditions, to low expectations for the future, as did low approval levels for administration performance and high levels of anomie. Moreover, low administration performance evaluation influenced voting behavior via low cabinet support, low political satisfaction, and loss of support for the ruling party. Low expectations for the future also connected to voting behavior through low cabinet support. Finally, in the 2012 Lower House elections, it is possible to discern a path whereby a high degree of anomie connected to voting behavior via low expectations for the future and declining support for the opposition (e.g., the LDP) and the cabinet.

As is clear from the above, since it is not possible to say that "after shifting to an SMD system, "issue attitude voting" is increasing," Hypothesis II appears to have been validated. In summary, there is a limit at least to the issue-attitude voting in SMD. The analysis does not deny that the issue has influenced voting behavior, but it may explain that at least the issue attitude voting is structurally greater than non-issue attitude voting in SMD.

\section{Testing Hypothesis II (b)}

To further test Hypothesis II, we analyzed, not only the subjective political consciousness of voters but also the correlation between candidate campaign promises and election results. In previous research related to democratic indicators, external indicators were used, such as the frequency of changes of government, the ratio of seats and votes secured by the ruling and opposition parties, and voter turnout (Przeworski, 2000). But the question for this paper is, "If changes of government are infrequent or if the ruling party has a high number of seats and voter, and, moreover, voter turnout is low, is it possible to say that representative democracy is not working?" In this sense, this paper attempts to expand the conventional indicators of representative democracy from external indicators to functional indicators. We are not asserting that "election pledges should always be fulfilled," realizing as we do that such a principle may become impractical if sudden, unexpected events (e.g., war) occur. However, the subject of analysis in this section is the Lower House between 2005 and 2012, a period without war. With this in mind, we analyzed the Lower House during this timeframe based on the question highlighted above.

The subjects of analysis in this section are campaign pledges (as stated in campaign bulletins) for Lower House elections in 2005, 2009, and 2012, and the minutes 
of remarks made at all Lower House plenary sessions and in its 11 committees, ${ }^{7}$ as well as data related to voting on legislation in the Lower House during the same period. Both data include support for/opposition to various proposals ${ }^{8}$ and coded data for remarks connected to increases/cuts in budget spending in different policy areas. $^{9}$

This paper focuses on the functioning of democracy, instead of conventional external indicators related to democracy, and measures the "quality" of democracy in a country where democracy has already been established. Specifically, we sought to establish whether citizens are selecting policymaking elites based on the party platforms these competing elites offer, that is, whether, "after shifting to an SMD system, "issue attitude voting" is increasing."

In Table 4, we first examined the correlation between the campaign pledges publicly made by candidates when announcing their bids to run in SMDs in the 2012 Lower House elections and the percentage of votes they won. For this analysis, we chose Model I, which does not include political party affiliation (as known by a candidate's official endorsement by a political party or a party's principal recommendation of an independent candidate) as an explanatory variable, and Model II, which includes party affiliation. In Model I, among campaign pledges, those related to issue areas such as transport and communication, constitutional revision, TPP, nuclear power plants, and consumption tax showed a significant correlation with the percentage of votes won. However, in Model II, which incorporates candidates' party affiliations, those affiliations (e.g., with the LDP) had strong, significant correlations with the percentages of votes won in the 2012 Lower House elections, while campaign pledges that correlated with percentages of votes won were limited to those related to approval/disapproval of a consumption tax rate hike and increases/ cuts in budget spending related to areas such as disaster prevention, agriculture, forestry, and fisheries. Moreover, beta values for individual campaign pledges are lower than for party affiliation.

For example, over $80 \%$ of LDP candidates who ran in SMDs won, whereas all Japanese Communist Party (JCP) candidates running in SMDs lost. Moreover, the campaign pledges of the LDP candidates and the JCP candidates clearly showed

\footnotetext{
7 Budget; Cabinet; General Affairs: Foreign Affairs: Education, Culture, Science and Technology; Health, Labor and Welfare; Agriculture, Forestry and Fisheries: Economy, Trade and Industry; Land, Infrastructure, Transport and Tourism; Environment; and Security.

8 For 2005 Lower House elections, this includes pension system reform, tax increases, postal services, etc.; for 2009 elections, constitutional revision, postal system privatization, late-life elderly medical care system reform, consumption tax changes, wage gap disparities, and pension system reform; and, for 2012 elections, constitutional revision, participation in negotiations for the Trans-Pacific Partnership (TPP) trade agreement, restarting of nuclear power plants, a consumption tax rate increase, together with coding for the presence/absence of remarks on Diet seat reduction, territorial problems, and earthquake recovery.

9 For 2012 Lower House elections, this includes social welfare and public assistance; health and hygiene (medical care); education; labor; defense; foreign policy and trade; agriculture, forestry, and fisheries; commerce, industry, and mining; transport and communications; local autonomy; housing; small and medium size enterprises; land development; disaster prevention; general administration; justice and the police; and government bonds. For 2005 and 2009 Lower House elections, "disaster prevention" was replaced with "other," and education and labor were grouped together into one policy area.
} 
Table 4 Correlations between campaign pledges and percentages of votes in 2012 Lower House elections (OLS)

\begin{tabular}{|c|c|c|c|c|c|c|c|c|}
\hline & \multicolumn{4}{|c|}{2012 Lower House (AlI) } & \multirow{2}{*}{\multicolumn{2}{|c|}{$\begin{array}{c}2012 \text { Lower House } \\
\text { (LDP) }\end{array}$}} & \multirow{2}{*}{\multicolumn{2}{|c|}{$\begin{array}{l}2012 \text { Lower House } \\
\text { (DPJ) } \\
\text { Model II }\end{array}$}} \\
\hline & \multicolumn{2}{|c|}{ Model I } & \multicolumn{2}{|c|}{ Model II } & & & & \\
\hline & $\beta$ & $\mathrm{p}$ & $\beta$ & $\mathrm{p}$ & $\beta$ & $\mathrm{p}$ & $\beta$ & $\mathrm{p}$ \\
\hline Social welfare/public assistance & .017 & .483 & .018 & .350 & -.033 & .605 & -.009 & .905 \\
\hline Health and hygiene (medical care) & -.016 & .515 & -.021 & .271 & -.078 & .219 & .050 & .523 \\
\hline Education & .063 & .006 & -.017 & .340 & -.141 & .023 & -.037 & .581 \\
\hline Labor & .005 & .799 & .000 & .978 & -.001 & .993 & -.041 & .551 \\
\hline Defense & -.008 & .706 & -.029 & .101 & -.051 & .405 & -.027 & .678 \\
\hline Foreign policy and trade & .059 & .011 & -.011 & .565 & -.062 & .318 & .024 & .727 \\
\hline Agriculture, forestry, and fisheries & .040 & .095 & .065 & .001 & .151 & .025 & .047 & .540 \\
\hline Commerce, industry, and mining & .008 & .707 & -.030 & .085 & -.101 & .102 & .001 & .994 \\
\hline Transport and communications & .091 & .000 & .048 & .007 & .092 & .138 & .027 & .714 \\
\hline Local autonomy & .053 & .019 & .055 & .002 & .003 & .961 & .014 & .831 \\
\hline Housing & -.057 & .008 & -.016 & .352 & -.047 & .436 & -.050 & .453 \\
\hline Small and medium size enterprises & .020 & .354 & .012 & .475 & .099 & .093 & -.076 & .279 \\
\hline Land development & .063 & .004 & .023 & .173 & -.002 & .978 & .138 & .044 \\
\hline Disaster prevention & .175 & .000 & .068 & .000 & .159 & .011 & .144 & .041 \\
\hline General administraion & .011 & .637 & -.016 & .394 & .049 & .435 & -.028 & .667 \\
\hline Justice and the police & -.002 & .940 & -.003 & .875 & -.003 & .962 & -.033 & .614 \\
\hline Government bonds & .049 & .019 & .027 & .097 & .028 & .633 & -.050 & .435 \\
\hline Constitutional revision & .186 & .000 & .057 & .036 & .097 & .112 & .032 & .620 \\
\hline TPP & -.163 & .000 & -.031 & .187 & -.053 & .393 & -.044 & .516 \\
\hline Restarting of nuclear power plants & .146 & .000 & -.009 & .662 & .056 & .377 & -.032 & .633 \\
\hline Consumption tax rate increase & .327 & .000 & .121 & .000 & .050 & .385 & -.003 & .966 \\
\hline Diet seat reduction & .041 & .083 & .046 & .013 & .015 & .809 & .148 & .029 \\
\hline Territorial problems & -.029 & .319 & .009 & .729 & .036 & .532 & -.031 & .632 \\
\hline Earthquake recovery & .060 & .005 & .008 & .618 & -.079 & .209 & .031 & .629 \\
\hline LDP & & & .627 & .000 & & & & \\
\hline DPJ & & & .145 & .000 & & & & \\
\hline Clean Government Party (Komeito) & & & .134 & .000 & & & & \\
\hline Social Democratic Party & & & -.014 & .424 & & & & \\
\hline Japan Communist Party & & & -.129 & .000 & & & & \\
\hline Adjusted R-square & .45 & & .66 & & .10 & & .002 & \\
\hline $\mathrm{N}$ & 12 & & 12 & & 28 & & 264 & \\
\hline
\end{tabular}

different trends. It is thus possible that the correlation found in Model I between campaign pledges and percentages of votes won is only a "pseudo correlation." To confirm whether there is a significant correlation between campaign pledges and percentages of votes won even when the influence of party affiliation is excluded, we conducted an analysis limited to LDP candidates. The results showed only increases/ reductions in budget spending, related to disaster prevention, education, agriculture, forestry, and fisheries, indicated such a correlation. Campaign pledges related to budgets and issues in other areas showed no significant correlation with percentages of votes won. The results of an analysis restricted to DPJ candidates who ran in SMDs similarly indicated a significant correlation only between percentages of votes won and remarks on increases/decreases in budget spending related to disaster prevention and national land development, and on a reduction in Diet seats, with no significant correlations found in other areas. In addition, the (adjusted) coefficient of determination was remarkably low in both the analysis of LDP candidates and DPJ 
candidates. Particularly regarding DPJ candidates, this value (0.002) indicated that campaign pledges alone cannot adequately explain the percentages of votes won.

We next conducted a logit regression analysis with the explained variable of winning/losing in the 2012 Lower House elections. We did this because, while there is a tendency to assume that "percentages of votes won by winners are high, and percentages of votes won by losers are low," excluding candidates having won particularly high or low (e.g., fringe candidates) percentages of votes, the percentages of votes won by a considerable number of candidates in SMDs are clustered between 43 and $56 \%$. Particularly in the $45 \%$ to $49 \%$ range, winning and losing candidates are completely mixed, and candidates did not necessarily win in descending order of the percentages of votes they secured. It is therefore necessary to conduct separate analyses of percentages of votes won and candidate wins/losses. In addition, because the methods used to analyze the percentage of votes won, which is a continuous variable, and to analyze win/loss, which is a dummy variable, are different, it is necessary to determine the effects this difference has on the results. The results of an analysis of all candidates in SMDs show that the LDP affiliation and JCP affiliation were significantly correlated with wins/losses in the 2012 Lower House elections, while only campaign pledges regarding the consumption tax rate and local government autonomy-related budget spending showed a significant correlation (Table 5). In an analysis focused only on LDP candidates, there were no campaign pledges that were significantly correlated with wins/losses. In an analysis focused only on DPJ candidates, only pledges regarding disaster-related budget spending showed a significant correlation. In other words, in SMD contests in the 2012 Lower House elections, there were hardly any campaign pledges that correlated with candidate wins/losses, though party endorsement was important in this regard. In addition, the results of a Hayashi's quantification theory class II analysis and a covariance structure analysis of voting behavior similarly failed to show issue voting to be significant, illustrating the difficulty of arguing that the will of the people is adequately mandated via campaign pledges in elections.

As previously mentioned, this paper's analyses of the effects of different factors on percentages of votes won and wins/losses in the 2012 Lower House elections did not examine the unique features of rival candidates or regions due to the special characteristics of the SMD system. In principle, DPJ candidates, LDP (or Komeito) candidates, and other candidates run in SMDs, and indicators for "competitors" show a DPJ candidate always running against an "LDP (or Komeito) candidate + other candidate(s)," and an LDP candidate always running against a "DPJ candidate + other candidate(s)." The variation across SMDs in the competitors faced by candidates from the same party is therefore limited, and the variable for candidate party affiliation has already been incorporated into the explanatory variables for the analysis of the percentage of votes won and wins/losses as explained variables, meaning that the effect of adding the party affiliations of competitors as another explanatory variable would be slight. Further, while the content of "other candidates" varies across SMDs, given that such candidates won in about $5 \%$ of all SMDs in the 2012 Lower House elections, this variation and its impact on the analysis are small. The same also applies to the features of individual electoral districts, where there are nearly 300 winners and nearly 300 losers in 300 SMDs if 
Table 5 Correlations between campaign pledges and seats won/lost in 2012 Lower House election (logit regression analysis)

\begin{tabular}{|c|c|c|c|c|c|c|c|c|}
\hline & \multicolumn{4}{|c|}{2012 Lower House (All) } & \multirow{2}{*}{\multicolumn{2}{|c|}{$\begin{array}{l}2012 \text { Lower House } \\
\text { (LDP) } \\
\text { Model I }\end{array}$}} & \multirow{2}{*}{\multicolumn{2}{|c|}{$\begin{array}{l}2012 \text { Lower House } \\
\text { (DPJ) }\end{array}$}} \\
\hline & \multicolumn{2}{|c|}{ Model I } & \multicolumn{2}{|c|}{ Model II } & & & & \\
\hline & $B$ & $p$ & $\mathrm{~B}$ & $p$ & $B$ & $p$ & $\mathrm{~B}$ & $p$ \\
\hline Social welfare/public assistance & -.022 & .899 & .107 & .627 & .023 & .974 & -.108 & .786 \\
\hline Health and hygiene (medical care) & -.083 & .674 & -.178 & .494 & .050 & .950 & -.203 & .631 \\
\hline Education & .777 & .000 & .359 & .117 & -.700 & .297 & .367 & .380 \\
\hline Labor & .282 & .095 & .225 & .301 & -.483 & .511 & .518 & .188 \\
\hline Defense & .109 & .650 & -.303 & .348 & -.896 & .266 & .067 & .920 \\
\hline Foreign policy and trade & .569 & .005 & -.136 & .607 & -.647 & .355 & .794 & .102 \\
\hline Agriculture, forestry, and fisheries & -.225 & .274 & .012 & .964 & .215 & .802 & -.801 & .084 \\
\hline Commerce, industry, and mining & .204 & .287 & .084 & .733 & -.072 & .926 & .121 & .751 \\
\hline Transport and communications & .454 & .041 & .315 & .287 & .699 & .441 & -.020 & .968 \\
\hline Local autonomy & .572 & .003 & .582 & .012 & - & - & .144 & .765 \\
\hline Housing & -3.366 & .019 & -2.343 & .168 & - & - & - & - \\
\hline Small and medium size enterprises & -.051 & .806 & -.082 & .774 & 1.359 & .231 & -.932 & .063 \\
\hline Land development & .959 & .014 & .676 & .206 & -1.580 & .109 & 1.324 & .120 \\
\hline Disaster prevention & .915 & .000 & .468 & .088 & .837 & .305 & .952 & .027 \\
\hline General administraion & -.229 & .274 & -.448 & .062 & -1.018 & .411 & -.454 & .312 \\
\hline Justice and the police & -.848 & .296 & -1.091 & .241 & -2.023 & .191 & - & - \\
\hline Government bonds & .672 & .546 & -.191 & .877 & - & - & - & - \\
\hline Constitutional revision & 1.143 & .000 & .513 & .104 & 1.103 & .343 & .323 & .674 \\
\hline TPP & -.848 & .000 & -.148 & .500 & -.086 & .904 & -.823 & .097 \\
\hline Restarting of nuclear power plants & .864 & .000 & -.126 & .538 & -1.529 & .171 & -.040 & .908 \\
\hline Consumption tax rate increase & 1.525 & .000 & 1.047 & .000 & -.201 & .896 & .803 & .092 \\
\hline Diet seat reduction & .040 & .858 & .167 & .520 & -.643 & .620 & .363 & .360 \\
\hline Territorial problems & -.141 & .621 & .145 & .751 & .190 & .872 & .356 & .636 \\
\hline Earthquake recovery & .838 & .000 & .574 & .053 & -.449 & .632 & .536 & .270 \\
\hline LDP & & & 4.148 & .000 & & & & \\
\hline DPJ & & & -.238 & .354 & & & & \\
\hline Clean Government Party (Komeito) & & & - & - & & & & \\
\hline Social Democratic Party & & & -.156 & .850 & & & & \\
\hline Japan Communist Party & & & -2.346 & .007 & & & & \\
\hline Cox \& Snell R-square & .332 & & .48 & & .058 & & .103 & \\
\hline Nagelkerke R-square & .332 & & .48 & & .161 & & .159 & \\
\hline N & 1294 & & 129 & & 220 & & 258 & \\
\hline
\end{tabular}

"other candidates" (i.e., not DPJ or LDP (or Komeito) candidates) are ignored. In other words, since there are equal numbers of winners and losers in electoral districts, when "other candidates" are excluded, the effect of including the features of electoral districts as an explanatory variable in the analysis of wins/losses as the explained variable is small. Similarly, because the sum of the percentages of votes won by DPJ candidates and LDP (or Komeito) candidates in each SMD is almost constant, little effect is seen by including the features of electoral districts as an explanatory variable in an analysis with percentages of votes won as a dependent variable.

Having examined the correlation between candidate campaign pledges and election results, it cannot be said that "issue attitude voting is increasing after the shift to an SMD," thus apparently verifying Hypothesis II. 


\section{Testing Hypothesis III (a)}

Policy debate involves not only a discussion of the policies but requires that the people's will, as mandated by voters via the "policy debate" at election time, be reflected in policies. We therefore tested Hypothesis III: There is no indication that, "after shifting to an SMD system, the will of the people as mandated at the time of the election is being reflected in policies." Specifically, we examined whether politicians elected in the 2009 Lower House elections engaged in legislative activity in line with their campaign pledges in the Diet between those elections and the next Lower House elections in 2012. We collected the minutes of all Lower House plenary sessions and the 11 committees for the period, and analyzed votes on related bills together with the contents of questions, replies, and other remarks based on categories used in the analysis of campaign pledges.

In addition, by crosschecking the analysis of election pledges during the 2009 Lower House elections, for each Lower House member, against the results of the analysis of their subsequent votes on bills and the contents of their remarks at Lower House plenary sessions and committees, we measured the degree of consistency between the two. Since not all Lower House members make "remarks" in that body, and the frequency of the remarks varies across members, it is necessary not only to analyze remarks but also votes on bills, which all members do with the same frequency.

The results of this analysis, when looking at the distribution of consistency between campaign pledges and Diet votes, show the degree of consistency to be low overall (Fig. 1). In addition, in terms of political parties, the degree of consistency between campaign pledges and post-election votes on bills in the Diet was high overall for the ruling DPJ, while the degree of consistency between campaigns pledges and post-election activities in the Diet for the LDP was comparatively low.

We next examined what type of factors determined the degree of consistency between election pledges and parliamentary activities. We employed three models for this analysis: Model I, which uses only social attributes as explanatory variables; Model II, which adds party affiliation and the number of election platform items,

Fig. 1 Degree of consistency: 2009 House of Representatives campaign pledges and Diet votes (2009-12)

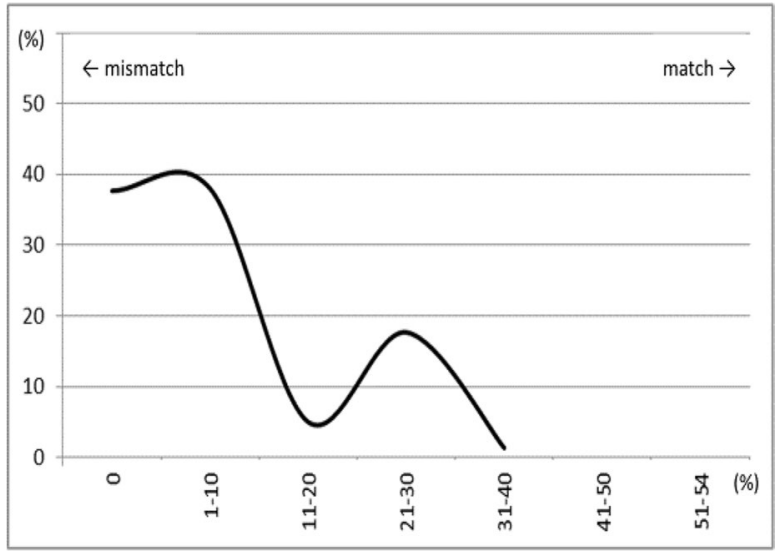


and Model III, which also adds career background. First, when all items (increases/ decreases in budget spending and issues supported/opposed in the context of election pledges) are considered, no explanatory factor showed a significant correlation with the degree of consistency in either Model I or Model II, and in Model III, only the number of election platform items showed a significant value.

An analysis of the degree of consistency between support for increases/decreases, in budget spending in the context of campaign promises and parliamentary activities, showed that the number of election platform items and the Social Democratic Party were significantly correlated. In addition, when analyzing the consistency of the issues they supported/opposed, such as consumption tax and nuclear power plants in the context of campaign pledges and parliamentary activities, candidates who had headed local or regional governments, LDP affiliation, and the number of election platform items demonstrated a significant value. Specifically, candidates who made a large number of campaign pledges tended, after the election, to engage in parliamentary activities that conformed to pledges, whereas candidates who had headed local or regional governments displayed the opposite tendency.

We also compared the results of these analyses with those of an analysis of the degree of consistency between campaign pledges in the 2005 Lower House elections and activities in the Diet between 2005 and 2009. The results similarly show a low degree of consistency overall, but it seems the degree of consistency for DPJ lawmakers was higher in 2009, when they were the ruling party, than in 2005 to 2009, when they were the opposition. In addition, a similar tendency was seen regarding the determinants of the degree of consistency.

Given these findings, Hypothesis III is considered verified since there is no indication that "after shifting to an SMD system, the will of the people as mandated at the time of the election is being reflected in policies."

\section{Testing Hypothesis III (b)}

There is only a tenuous correlation between campaign pledges made at the time of an election and subsequent parliamentary activities. However, if the degree of consistency between politicians' campaign pledges and their parliamentary activities is reflected in the results of the next election, taking the long view, politicians would have to fulfill the campaign pledges they make to voters before that election, which for voters would mean that politics is operating based on the will of the people as voters mandated it. On the other hand, if a lack of consistency between candidates' campaign pledges and their parliamentary activities has no effect on the next election's results, politicians can ignore the campaign promises made in the previous election. We thus next examined whether the degree of consistency between campaign pledges and parliamentary activities was reflected in the results of the subsequent election.

We first conducted a multiple regression analysis with "the percentage of votes won in 2012 Lower House elections" as the explained variable, and "the degree of consistency between campaign pledges made in 2009 Lower House elections and voting on bills (related to issues supported/opposed and increases/decreases in 
budget spending in pledges) in the Lower House from 2009 onwards" and "politician social attributes" as explanatory variables. We employed three models for this analysis: Model I, which uses only the degree of consistency, social attributes, and regional characteristics of SMDs as explanatory variables; Model II, which adds political party affiliation; and Model III, which also adds career background.

The results show that, when all items in plenary sessions (i.e., support for/opposition to bills and budget spending items on which positions had been indicated in campaign pledges) were considered, the degree of consistency in all three models showed no significant correlation with percentages of votes won in the 2012 Lower House elections (Table 6). Similarly, no significant correlation was seen between percentages of votes won and either the degree of consistency for only budget items or only bills approved/opposed in the plenary session.

On the other hand, an analysis of both plenary sessions and committees showed that the higher the degree of consistency between campaign pledges made in the 2009 Lower House elections and parliamentary activities from those elections onwards, the higher the percentage of votes won in 2012 Lower House elections. Furthermore, separate analyses of plenary sessions and committees regarding approval of/opposition to budget items and bills approved/opposed showed the degree of consistency for budget items correlated with the percentage of votes won, while the degree of consistency for bills approved/opposed had no significant correlation. These findings indicate that, particularly in the case of budget items in committees, the degree of consistency between campaign pledges and parliamentary activities was correlated with the percentage of votes won in the next instance of Lower House elections.

However, the percentage of votes won in Lower House elections depends on the number of candidates in each electoral district. Thus, possibly, there is only the appearance of a correlation between the "degree of consistency between campaign pledges and parliamentary activities" and "percentage of votes won in the next instance of Lower House elections in 2012." To explore this issue, we conducted a logit regression analysis with wins/losses in the 2012 Lower House elections as the explained variable. The results found no significant correlation between the "degree of consistency between campaign pledges and parliamentary activities" and "percentages of votes won in the next instance of Lower House elections" in any of Models I-III when considering all items in plenary sessions (i.e., support for/ opposition to bills and budget spending items on which positions had been indicated in campaign pledges); by individual item in plenary sessions; all items in plenary sessions + committees; or by individual item in plenary sessions + committees (Table 7). Consequently, in an extreme case scenario, whether a politician fulfilled the campaign pledges made to the voters in the 2009 Lower House elections did not affect the outcome of that politician's reelection bid in the next Lower House elections in 2012.

We then compared these results with the results of analyses of the correlation between "the degree of consistency between campaign pledges in the 2005 Lower House elections and parliamentary activities between 2005 and 2009" and both "percentages of votes won in the following 2009 Lower House elections" and "wins/ losses in the following 2009 Lower House elections." We found that, in the analysis 
Table 6 Degree of consistency between campaign pledges in 2009 Lower House elections and parliamentary activities (2009-2012), percentages of votes in 2012 Lower House elections (OLS)

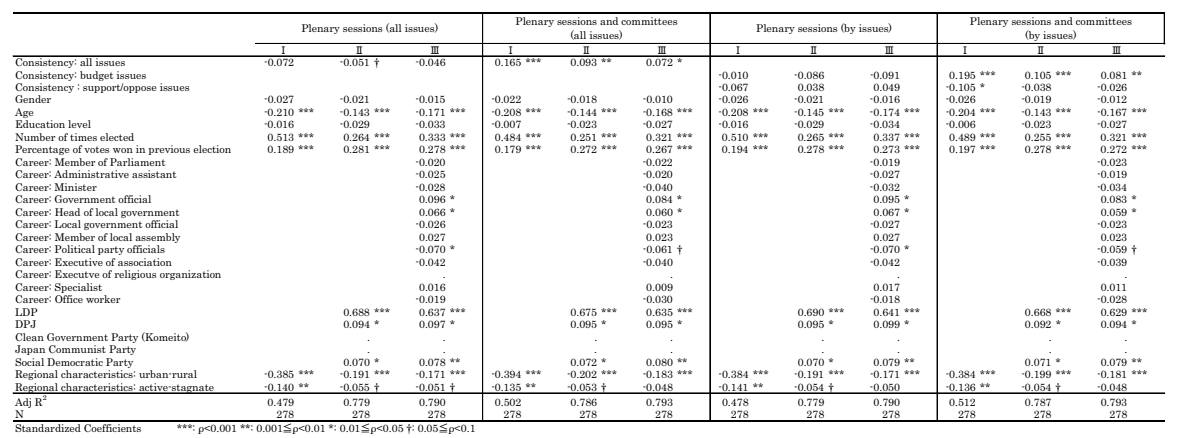

of the 2005-2009 timeframe as well, the degree of consistency between campaign pledges and parliamentary activities did not show a significant correlation with wins/losses in the following (2009) Lower House elections, indicating that the lack of such a correlation was not a problem only for the 2009-2012 period and the 2012 Lower House elections. The analysis of the 2005-2009 timeframe also showed the degree of consistency between campaign pledges and parliamentary activities had no correlation with the percentages of votes won in the 2009 Lower House elections.

All of these analyses relate to whether politicians fulfilled the campaign pledges they made to voters during elections through their subsequent parliamentary activities and whether this degree of consistency affected the next Lower House elections. To confirm our findings in this area, we conducted a more voter-centric analysis, using political consciousness survey data (JES III, IV, and V) for the 2005, 2009, and 2012 Lower House elections, to determine whether voting took place in line with evaluations of politician performance. Specifically, we performed a logit regression analysis using votes for/against the LDP as an explanatory variable. The results showed that voter evaluation of the cabinet's performance was not a significant determinant of voting behavior in the 2005 or 2009 Lower House elections, while in the 2012 Lower House elections, voter evaluation of cabinet performance

Table 7 Consistency between campaign pledges in 2009 Lower House elections and parliamentary activities (2009-2012), seats won/lost in 2012 Lower House elections (logit regression analysis).

\begin{tabular}{|c|c|c|c|c|c|c|c|c|c|c|c|c|}
\hline & \multicolumn{3}{|c|}{ Plenary sessions (all issues) } & \multicolumn{3}{|c|}{$\begin{array}{l}\text { Plenary sessions and committees } \\
\text { (all issues) }\end{array}$} & \multicolumn{3}{|c|}{ Plenary sessions (by issues) } & \multicolumn{3}{|c|}{$\begin{array}{c}\text { Plenary sessions \& committees } \\
\text { (by issues) }\end{array}$} \\
\hline Consistancy; all issues & -0.267 & II & $\frac{\text { III }}{.0372}$ & $\frac{1}{10 x}$ & III & III & $\mathrm{I}$ & II & III & 1 & & \\
\hline $\begin{array}{l}\text { Consistencyy' budget issues } \\
\text { Constist }\end{array}$ & & & & & & & & & & & & \\
\hline $\begin{array}{l}\text { Consistency's supportloppose issues } \\
\text { Giender }\end{array}$ & & & & & & & -0.893 & -0.070 & 1.211 & $-1.524 \dagger$ & & 0.231 \\
\hline $\begin{array}{l}\text { Gender } \\
\text { Age }\end{array}$ & $\begin{array}{l}-1.272 \\
-0.049 \\
\text { * }\end{array}$ & & 2.146 & $\begin{array}{l}1.273 \\
-0.048\end{array}$ & ${ }_{-0.065}^{1.778}$ * & $\stackrel{2.046}{-0.080 *}$ & $\begin{array}{l}1.268 \\
-0.049\end{array}$ & $\begin{array}{l}-1.897 \\
-0.067 \%\end{array}$ & $=2.175$ & $\begin{array}{l}-1.343 \\
-0.09 *\end{array}$ & $\begin{array}{l}1.785 \\
0.0066\end{array}$ & -2.036 \\
\hline $\begin{array}{l}\text { Age } \\
\text { Education level }\end{array}$ & $\begin{array}{l}-0.049 \times \\
0.308\end{array}$ & ${ }_{0.552}^{-0.067}$ & $\begin{array}{l}0.079^{\circ} \\
0.680\end{array}$ & $\begin{array}{l}-0.048 \times \\
0.418\end{array}$ & ${ }_{0.693}^{-0.065}$ & $\begin{array}{l}-0.0800^{*} \\
0.831\end{array}$ & $\begin{array}{l}0.049^{*} \\
0.308\end{array}$ & $\begin{array}{l}-0.0677^{*} \\
0.553\end{array}$ & 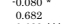 & $\begin{array}{l}0.049 * \\
0.450\end{array}$ & $\begin{array}{l}-0.0666^{\circ} \\
0.736\end{array}$ & 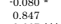 \\
\hline 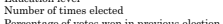 & 0.619 the & $0.578 * * *$ & 0.675 & $0.566^{* 4 *}$ & 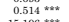 & $0.669 * * *$ & & 0.578 * * * & $0.683 * 4 * 4$ & $0.585 * * *$ & $0.528 * * \mathrm{k}$ & $0.667 .40 \%$ \\
\hline $\begin{array}{l}\text { Percentage of votes won in previous election } \\
\text { Career: Member of Parliament }\end{array}$ & 3.729 & 15.099 *** & $\begin{array}{l}15.566 \\
0.518\end{array}$ & 3.986 & 15.196 \#* & $\begin{array}{l}14.158 * * * \\
0.690\end{array}$ & 3.894 & $15.060 * * *$ & $\begin{array}{l}15.1277^{* k *} \\
0.536\end{array}$ & $4.680 \uparrow$ & $15.438^{* * * *}$ & $\begin{array}{l}14.381 \% * * * \\
0.698\end{array}$ \\
\hline Career: Administrative assistant & & & $=0.171$ & & & $\begin{array}{l}-1.071 \\
-1.071\end{array}$ & & & -1.212 & & & $\begin{array}{l}-1.053 \\
-1.053\end{array}$ \\
\hline Career: Minister & & & .0 .250 & & & -1.393 & & & -0.401 & & & -1.285 \\
\hline Career: Government official & & & 0.623 & & & 0.630 & & & 0.640 & & & 0.643 \\
\hline $\begin{array}{l}\text { Career: Head of oforal government } \\
\text { Career: Local government official }\end{array}$ & & & $\begin{array}{l}-1.409 \\
.0 .007\end{array}$ & & & $\begin{array}{l}-1.705 \\
0.121\end{array}$ & & & $\begin{array}{l}-1.409 \\
-0.026 \\
-10\end{array}$ & & & -1.713 \\
\hline $\begin{array}{l}\text { Career: Local government oftcial } \\
\text { Career: Member of local assembly }\end{array}$ & & & $\begin{array}{l}0.007 \\
0.259\end{array}$ & & & 0.250 & & & $\begin{array}{l}-0.269 \\
0.269\end{array}$ & & & $\begin{array}{l}0.264 \\
0.264\end{array}$ \\
\hline Career: Political party officials & & & $\cdot 1.216$ & & & $\begin{array}{r}-0.062 \\
-1.062\end{array}$ & & & -1.216 & & & -1.044 \\
\hline $\begin{array}{l}\text { Career: Executive of association } \\
\text {. }\end{array}$ & & & .0 .730 & & & -0.608 & & & -0.715 & & & 0.584 \\
\hline $\begin{array}{l}\text { Caraeer: Executve of religious organization } \\
\text { Career: Specialilist }\end{array}$ & & & $\begin{array}{l}0.000 \\
0.402\end{array}$ & & & 0.000 & & & 0.000 & & & 0.000 \\
\hline $\begin{array}{l}\text { Careerer : Specialist } \\
\text { Career worker }\end{array}$ & & & $\begin{array}{l}0.402 \\
0.127\end{array}$ & & & $\begin{array}{l}0.150 \\
-0.150\end{array}$ & & & $\begin{array}{c}0.425 \\
-0.124\end{array}$ & & & 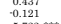 \\
\hline LDP & & $5.741 * * *$ & $5.904 * * *$ & & 5.435 *** & $5.721 * * *$ & & 5.748 *** & $5.939 \mathrm{kk*}$ & & $5.452 * * *$ & $5.722 * * *$ \\
\hline & & -0.257 & $\cdot 0.231$ & & -0.409 & -0.386 & & -0.253 & -0.215 & & & \\
\hline $\begin{array}{l}\text { Clean Government Party (Komeito) } \\
\text { Japan Communist Party }\end{array}$ & & & & & & & & & $\begin{array}{l}0.000 \\
0.000\end{array}$ & & $\begin{array}{l}0.000 \\
0.000\end{array}$ & $\begin{array}{l}0.000 \\
0.000\end{array}$ \\
\hline Social Democratic Party & & 16.429 & 16.656 & & 16.787 & 16.495 & & 17.434 & 16.641 & & 16.787 & 16.210 \\
\hline Regiona & -0.791 *** & & & $0.840^{* * *}$ & & & $0.791 * * *$ & & -0.200 & 0.842 *** & & \\
\hline $\begin{array}{l}\text { Regional characteristics; active'stagnate } \\
\text { constant }\end{array}$ & 0.251 & ${ }_{-8.51}^{0.107}$ * & ${ }_{-7755}^{0.074}$ & -0.262 & $\begin{array}{l}-0.114 \\
-9057 *\end{array}$ & -0.064 & 0.252 & 0.106 & -0.064 & -0.276 & 0.126 & 0.074 \\
\hline$\frac{\text { constant }}{\operatorname{Cox} \& \text { Snell R }{ }^{2}}$ & $\frac{2.393}{0.352}$ & 0.539 & 0.556 & $\frac{2.990}{0.361}$ & $\frac{.0 .534}{0.537}$ & 0.6525 & 0.352 & 0.0189 & 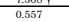 & 0.363 & $\frac{9.527}{0.538}$ & 0.5895 \\
\hline Nagelkerke $\mathrm{R}^{2}$ & 0.490 & 0.749 & 0.774 & 0.502 & 0.747 & 0.771 & 0.490 & 0.749 & 0.774 & 0.511 & 0.748 & 0.771 \\
\hline & & & & & & & & & & & & \\
\hline
\end{tabular}


Table 8 Voting behavior and administration performance evaluation (logit regression analysis) Voting behavior Vote for LDP: supporter of both cabinet and LDP

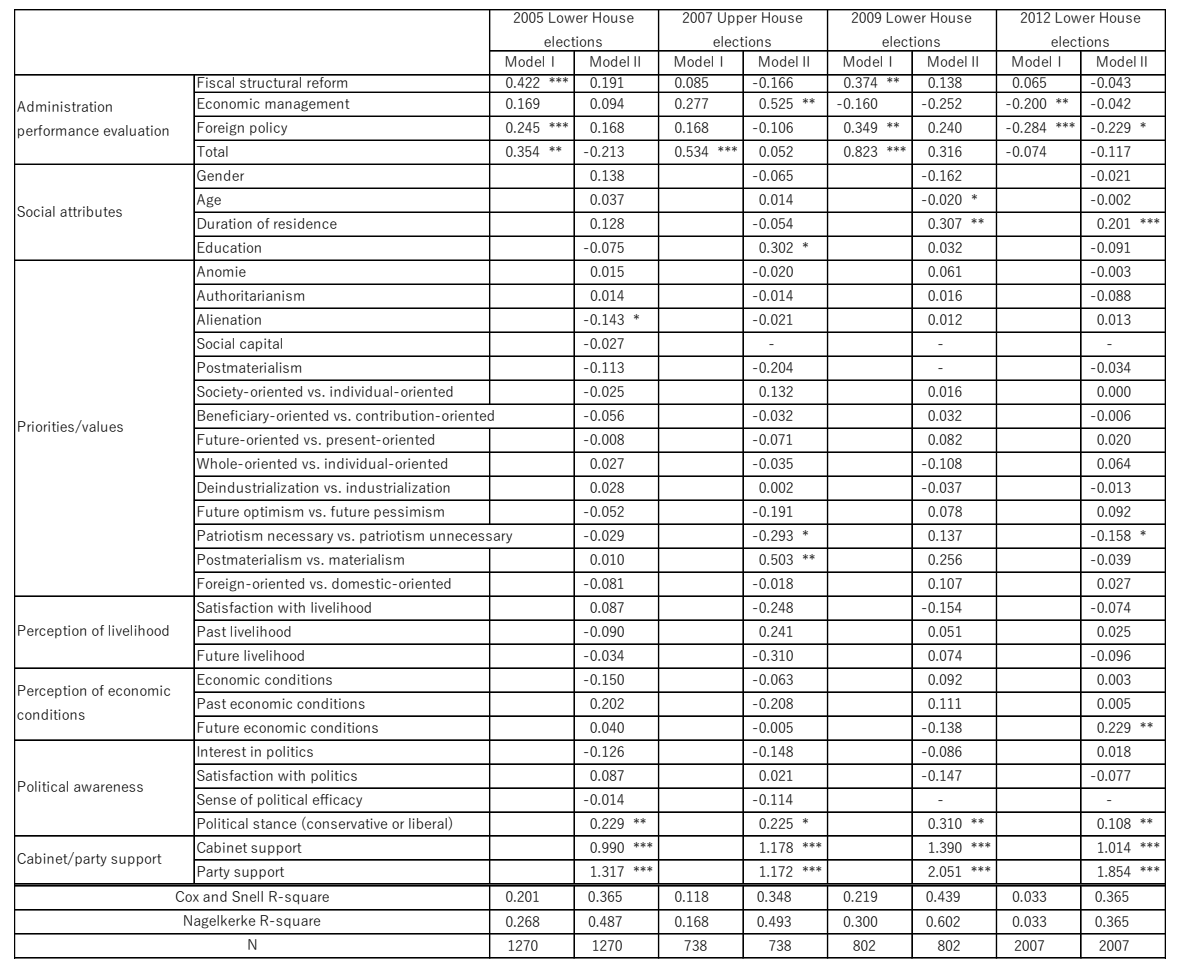

on foreign policy had a negative correlation (i.e., the less a voter approved of performance, the more likely he or she was to vote LDP) (Table 8), though it is possible that this is only a spurious correlation. When we conducted the same kind of analysis but divided voters according to the political parties they supported (i.e., LDP supporters, DPJ supporters, and unaffiliated voters), the results did not enable us to confirm that voting in line with performance evaluation occurred in the 2005, 2009, or 2012 Lower House elections (Tables 9 and 10). These results are similar to the results of our more politician-centric analyses.

Given these findings, it cannot be said that the degree of consistency between politicians' campaign pledges and parliamentary activities is reflected in the results of the subsequent election. With no indication that "after shifting to an SMD system, the will of the people as mandated at the time of the election is being reflected in actual policies," Hypothesis III is considered verified.

It is difficult to claim, either prospectively or retrospectively, that representative democracy is functioning in Japan. Stated differently, it cannot be said that the voters' will is being adequately mandated to politicians via elections. Specifically, since politicians are engaging in parliamentary activities and forming policies that differ from their campaign pledges to voters, voters' sense of political efficacy is extremely low, which means that, even in elections, voters make decisions without trusting 
Table 9 Voting behavior and administration performance evaluation (by support for political party) logit regression analysis (2009 Lower House elections) Voting behavior Vote for LDP: categorized by support for political party

\begin{tabular}{|c|c|c|c|c|c|c|c|}
\hline & & \multicolumn{6}{|c|}{2009 Lower House elections } \\
\hline & & \multicolumn{2}{|c|}{ Only LDP supporters } & \multicolumn{2}{|c|}{ Only DPJ supporters } & \multicolumn{2}{|c|}{ Only nonpartisan } \\
\hline & & Model I & Model II & Model I & Model II & Model I & Model II \\
\hline \multirow{4}{*}{$\begin{array}{l}\text { Evaluation of } \\
\text { administration } \\
\text { performance }\end{array}$} & Fiscal structural reform & 0.374 & 0.192 & 0.360 & -0.070 & -0.060 & -0.258 \\
\hline & Economic management & -0.261 & -0.273 & -0.282 & -1.706 & -0.291 & -0.682 \\
\hline & Foreign policy & 0.205 & 0.062 & 0.634 & 1.117 & 0.333 & 0.171 \\
\hline & Total & $0.721^{* * *}$ & 0.419 & 0.164 & -0.245 & $0.766^{*}$ & 0.072 \\
\hline \multirow{4}{*}{ Social attributes } & Gender & & 0.290 & & -0.399 & & -0.218 \\
\hline & Age & & -0.021 & & -0.101 & & -0.006 \\
\hline & Duration of residence & & $0.338^{*}$ & & 0.619 & & $0.691^{*}$ \\
\hline & Education & & 0.077 & & -2.227 & & 0.120 \\
\hline \multirow{14}{*}{ Priorities/values } & Anomie & & 0.103 & & -0.604 & & -0.036 \\
\hline & Authoritarianism & & 0.123 & & 0.620 & & -0.368 \\
\hline & \begin{tabular}{|l|} 
Alienation \\
\end{tabular} & & -0.058 & & 0.035 & & 0.084 \\
\hline & Social capital & & - & & - & & - \\
\hline & Postmaterialism & & - & & - & & - \\
\hline & Society-oriented vs. individual-oriented & & 0.113 & & 1.332 & & -0.454 \\
\hline & \multicolumn{2}{|l|}{ Beneficiary-oriented vs. contribution-oriented } & -0.010 & & -0.415 & & -0.643 \\
\hline & Future-oriented vs. present-oriented & & 0.042 & & 0.312 & & 0.384 \\
\hline & Whole-oriented vs. individual-oriented & & -0.161 & & -0.975 & & 0.287 \\
\hline & Deindustrialization vs. industrialization & & 0.128 & & -0.710 & & -0.375 \\
\hline & Future optimism vs. future pessimism & & -0.114 & & -1.173 & & 0.020 \\
\hline & \multicolumn{2}{|c|}{ Patriotism necessary vs. patriotism unnecessary } & 0.190 & & 0.830 & & 0.283 \\
\hline & Postmaterialism vs. materialism & & 0.343 & & $-3.295^{*}$ & & 0.526 \\
\hline & Foreign-oriented vs. domestic-oriented & & 0.167 & & -0.271 & & 0.246 \\
\hline \multirow{3}{*}{$\begin{array}{l}\text { Perception of } \\
\text { livelihood }\end{array}$} & Satisfaction with livelihood & & -0.151 & & -0.508 & & 0.286 \\
\hline & Past livelihood & & 0.328 & & -0.314 & & 0.499 \\
\hline & Future livelihood & & -0.190 & & -0.603 & & 0.011 \\
\hline \multirow{3}{*}{$\begin{array}{l}\text { Perception of } \\
\text { economic } \\
\text { conditions }\end{array}$} & Economic conditions & & 0.114 & & 1.161 & & 0.468 \\
\hline & Past economic conditions & & 0.009 & & -2.037 & & 0.333 \\
\hline & Future economic conditions & & -0.342 & & -2.077 & & -0.159 \\
\hline \multirow{4}{*}{ Political awareness } & Interest in politics & & 0.100 & & -1.335 & & -0.332 \\
\hline & Satisfaction with politics & & -0.196 & & 0.458 & & 0.041 \\
\hline & Sense of political efficacy & & - & & - & & - \\
\hline & Political stance (conservative or liberal) & & $0.273^{*}$ & & 0.317 & & $0.900^{* * *}$ \\
\hline \multirow{2}{*}{ Cabinet/party suppo } & Cabinet support & & $1.262^{* * * *}$ & & $5.525^{*}$ & & $1.757^{* * *}$ \\
\hline & Party support & & - & & - & & - \\
\hline & Cox and Snell R-square & 0.137 & 0.272 & 0.020 & 0.176 & 0.046 & 0.288 \\
\hline & Nagelkerke R-square & 0.193 & 0.383 & 0.065 & 0.578 & 0.075 & 0.466 \\
\hline & $\mathrm{N}$ & 326 & 326 & 225 & 225 & 171 & 171 \\
\hline
\end{tabular}

parties or politicians' campaign pledges. Moreover, it appears that voter selections of candidates in the next election are not in line with voter evaluations of policies being implemented.

\section{Testing Hypothesis IV}

It has become clear that, at least in the case of our examination of Lower House elections conducted under Japan's SMD system, the merits claimed for that system have not been validated. We next examined whether problems claimed for the MMD system are no longer visible now that this system has been eliminated. If problems associated with the MMD system have disappeared or are less prevalent in Lower House elections under the SMD system, this would prove the logic of arguments made when the parallel electoral system was introduced that "the fault lies with the electoral system." However, if the same problems occur in Lower House elections under the SMD system as occurred in elections under the MMD system, these problems are more intractable. In other words, "problems stemming from the MMD vote system" highlighted 
Table 10 Voting behavior and administration performance evaluation (by support for political party) logit regression analysis (2012 Lower House elections) Voting behavior Vote for LDP: categorized by support for political party

\begin{tabular}{|c|c|c|c|c|c|c|c|}
\hline & & \multicolumn{6}{|c|}{2012 Lower House elections } \\
\hline & & \multicolumn{2}{|c|}{ Only LDP supporters } & \multicolumn{2}{|c|}{ Only DPJ supporters } & \multicolumn{2}{|c|}{ Only nonpartisan } \\
\hline & & Model I & Model II & Model I & Model II & Model I & Model II \\
\hline \multirow{4}{*}{$\begin{array}{l}\text { Evaluation of } \\
\text { administration } \\
\text { performance }\end{array}$} & Fiscal structural reform & 0.160 & 0.337 & -0.153 & -0.398 & 0.190 & 0.060 \\
\hline & Economic management & -0.110 & -0.109 & -0.186 & 0.007 & -0.293 & -0.213 \\
\hline & Foreign policy & $-0.351 *$ & -0.291 & -0.161 & -0.239 & $-0.428^{* *}$ & -0.268 \\
\hline & Total & -0.166 & -0.296 & -0.215 & 0.023 & 0.089 & 0.030 \\
\hline \multirow{4}{*}{ Social attributes } & Gender & & -0.106 & & 1.079 & & 0.187 \\
\hline & Age & & 0.002 & & 0.018 & & 0.005 \\
\hline & Duration of residence & & $0.234^{*}$ & & $0.591^{*}$ & & $0.195 *$ \\
\hline & Education & & 0.024 & & 0.110 & & -0.210 \\
\hline \multirow{14}{*}{ Priorities/values } & Anomie & & 0.034 & & -0.376 & & -0.017 \\
\hline & Authoritarianism & & -0.129 & & -0.001 & & -0.053 \\
\hline & Alienation & & 0.111 & & 0.378 & & 0.021 \\
\hline & Social capital & & - & & - & & - \\
\hline & Postmaterialism & & -0.059 & & 0.663 & & -0.063 \\
\hline & Society-oriented vs. individual-oriented & & -0.172 & & 0.480 & & 0.028 \\
\hline & \multicolumn{2}{|l|}{ Beneficiary-oriented vs. contribution-oriented } & -0.033 & & -0.078 & & 0.076 \\
\hline & Future-oriented vs. present-oriented & & 0.056 & & -0.079 & & 0.151 \\
\hline & Whole-oriented vs. individual-oriented & & 0.264 & & 0.340 & & -0.179 \\
\hline & Deindustrialization vs. industrialization & & -0.100 & & -0.095 & & 0.041 \\
\hline & Future optimism vs. future pessimism & & 0.269 & & -0.119 & & 0.023 \\
\hline & \multicolumn{2}{|c|}{ Patriotism necessary vs. patriotism unnecessary } & $-0.496^{* *}$ & & -0.325 & & 0.013 \\
\hline & Postmaterialism vs. materialism & & 0.115 & & $-1.285^{* *}$ & & 0.079 \\
\hline & Foreign-oriented vs. domestic-oriented & & 0.142 & & -0.384 & & 0.021 \\
\hline \multirow{3}{*}{$\begin{array}{l}\text { Perception of } \\
\text { livelihood }\end{array}$} & Satisfaction with livelihood & & -0.017 & & 0.200 & & -0.057 \\
\hline & Past livelihood & & -0.255 & & 0.879 & & 0.060 \\
\hline & Future livelihood & & -0.238 & & -0.731 & & 0.057 \\
\hline \multirow{3}{*}{$\begin{array}{l}\text { Perception of } \\
\text { economic conditions }\end{array}$} & Economic conditions & & 0.128 & & -0.637 & & -0.053 \\
\hline & Past economic conditions & & -0.131 & & -0.026 & & 0.188 \\
\hline & Future economic conditions & & $0.529^{* *}$ & & -0.177 & & 0.096 \\
\hline \multirow{4}{*}{ Political awareness } & Interest in politics & & 0.094 & & 0.318 & & 0.019 \\
\hline & Satisfaction with politics & & 0.121 & & -0.273 & & -0.033 \\
\hline & Sense of political efficacy & & - & & - & & - \\
\hline & Political stance (conservative or liberal) & & 0.105 & & 0.153 & & $0.121 *$ \\
\hline \multirow{2}{*}{ Cabinet/party suppor } & Cabinet support & & $0.649^{* *}$ & & $1.818^{* * *}$ & & $1.115^{* * *}$ \\
\hline & Party support & & - & & - & & - \\
\hline & Cox and Snell R-square & 0.026 & 0.155 & 0.036 & 0.228 & 0.028 & 0.193 \\
\hline & Nagelkerke R-square & 0.042 & 0.246 & 0.063 & 0.398 & 0.041 & 0.281 \\
\hline & $\mathrm{N}$ & 593 & 593 & 257 & 257 & 749 & 749 \\
\hline
\end{tabular}

when the parallel system was introduced are not engendered by that system alone but are problems stemming from Japan's broader political architecture. To resolve them, it is not the electoral district system that must be fixed, but some other structure.

We next examined Hypothesis IV: "After shifting to an SMD system, the correlation between votes and subsidies has not disappeared." We began by determining whether any changes occurred in the "exchange system of votes for subsidies," which was said to be an affliction of the MMD system. When the MMD system was in use, this votes-for-subsides exchange purportedly came in two types: a "vote gathering" method, whereby subsidies were distributed to solicit votes in the next election, and a "vote appreciation" method, whereby subsidies were distributed according to votes received in the last election.

Looking first at special allocation tax grants, we found that, even when accounting for the effects of urbanization, there was a high correlation between percentages of votes won by the LDP in SMDs in the 1996 Lower House elections- the first held under the new electoral system - and grant amounts distributed to each of those districts in the previous year (1995). It thus appears that the so-called vote gathering 
method used in the "exchange system of votes for subsidies" 10 existed under the SMD system. Looking next at how percentages of votes won by the LDP in individual SMDs in the 1996 Lower House elections affected the distribution of special allocation tax grants across those districts in the following year (1997), there was a high correlation even when accounting for urbanization's effects. The so-called vote appreciation method used in the "exchange system of votes for subsidies" continued to exist. We found similar results when analyzing the effects of special allocation tax grants in 1999 on the 2000 Lower House elections, and the effects of those elections on grants in 2001, namely that there was a high correlation even when taking urbanization's effects into account. The same correlation can be seen in the 2003 Lower House elections (Fig. $2^{11}$ ). However, in the 2006 Lower House elections, which occurred after the Koizumi administration drastically reduced special allocation tax grants, these correlations were not significant. But in the 2009 Lower House elections, which occurred after special allocation tax grants increased following Koizumi's departure from office, these correlations became significant again. Then, in 2012 Lower House elections held under the DPJ administration, the correlation was again not significant.

In other words, we found that, while the "exchange system of votes for subsidies" continued even under the SMD system, the correlation between votes and subsidies (grants) was not significant in Lower House elections held either after the administration at the time (i.e., Koizumi) had reduced special allocation tax grants or after a change of government (i.e., from LDP to DPJ).

Furthermore, when analyzing the broader category of local allocation tax grants (ordinary allocation tax grants and special allocation tax grants combined) and examining the correlation between percentages of votes won by the LDP in SMDs in Lower House elections and grants received by those districts both before and after the elections, we found a high correlation (though not as high as for special allocation tax grants) even when again accounting for the effects of urbanization (Fig. $3^{12}$ ). In addition, this analysis also showed a trend where the correlation between votes and subsidies (grants) was not significant in Lower House elections held either after the administration at the time had reduced local allocation tax grants or after the change of government. It is clear that the "exchange system of votes for subsidies" considered an affliction of the MMD system remained in place under the SMD system. Thus, Hypothesis IV apparently has been proven.

We next examined whether the change in the Lower House electoral system affected the "exchange system for votes and subsidies" in the case of Upper House elections. After compiling data on construction subsidies received by individual municipalities and percentages of votes won by candidates who were supported by construction industry organizations and secured seats in the 2001 Upper House elections (held seven years after the Lower House electoral system was changed to

\footnotetext{
${ }^{10}$ For the "exchange system of votes for subsidies" under the SMD system, see Kobayashi, Yoshiaki. Contemporary Political Process of Japan. Tokyo University Press, 1997.

11 Due to space limitations, the figure shows only the part from 2005 to 2012. Please contact the author for the entire diagram since 1995 .

12 Due to space limitations, the figure shows only the part from 2005 to 2012. Please contact the author for the entire diagram since 1995.
} 


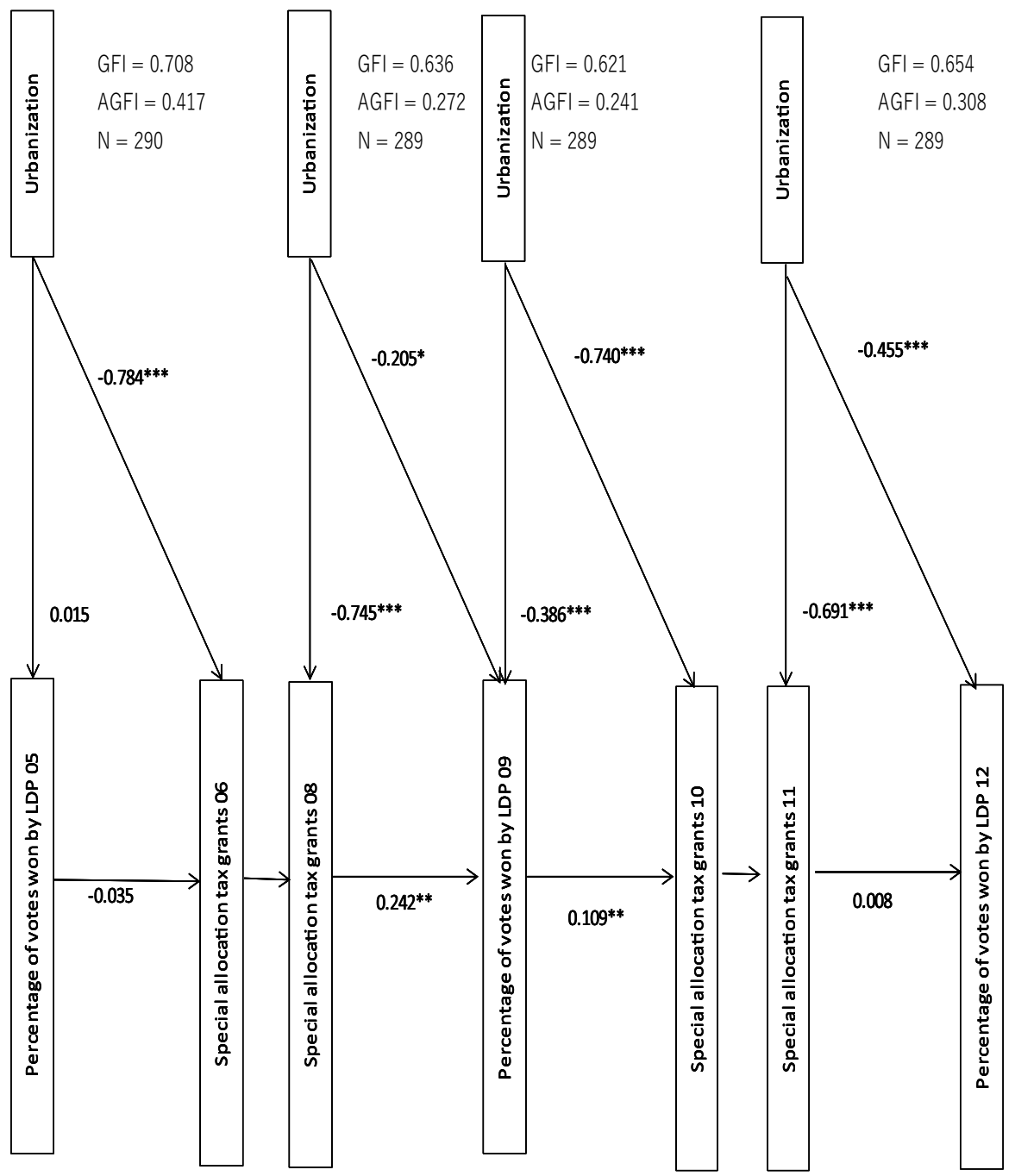

Fig. 2 Exchange system of votes for subsidies (special allocation tax grants, per capita)

a parallel system) and then re-tabulating these data by electoral district, we found a high correlation between vote percentages and subsidy amounts of $r=0.449$ $(\mathrm{N}=300)$. Though this correlation for Lower House elections held when the MMD system was in use was $r=0.700(\mathrm{~N}=130)$, when considering the differences between the cases (i.e., number of electoral districts in Lower House elections), they both show a high correlation. In addition, when examining the correlation between construction subsidies in 2000 and percentages of votes won by candidates supported by construction industry organizations in the 2001 Upper House elections, and the correlation between percentages of votes won by such candidates in the 2001 Upper House elections and construction subsidies in 2003, both are still high even when accounting for the effects of urbanization. 


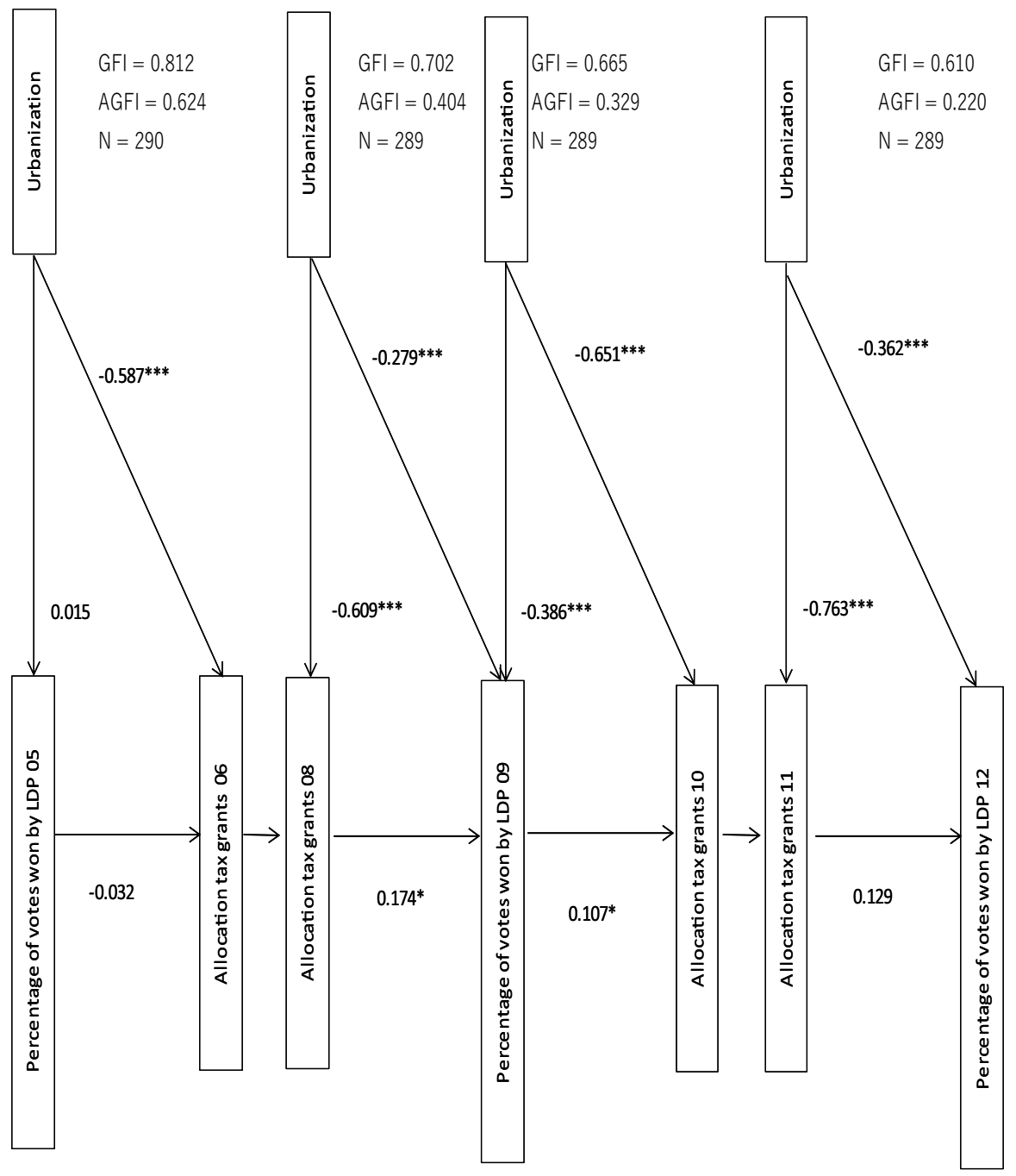

Fig. 3 Exchange system of votes for subsidies (allocation tax grants, per capita)

\section{Summary and Conclusion}

This paper demonstrated that the "advantages of the single-member system" claimed by its proponents at the time of the parallel system's introduction are not valid. It also showed that problems said to accompany the MMD system were occurring under the SMD system. From this, the problem of "politics and money" that caused distrust of politics at the time was not engendered by the electoral system but was instead a problem stemming from a different structural factor. This problem remained after the electoral system change, and time passed without the truly essential reforms being implemented. 
In Japan's case, single-member districts cannot be said to have increased voter choice, issue voting, and policy debate, nor better ensure that voters will determines the policies of elected representatives. Consequently, we cannot expect significant positive additions to voter engagement, knowledge, and objectivity, public discourse, and political liberties - our conductive characteristics of community wellbeing.

Our analyses have limitations. We conducted them based on available survey data such as the JES survey series and aggregate data available for individual municipalities such as subsidies. Though we intended to use all available data, there are inherent limitations to the extent they can be used to replicate real political phenomena. This paper can clearly prove that "so far as an examination of data used in it is concerned, the alleged advantages of the SMD system did not manifest themselves, and problems associated with the MMD system have not been resolved."

Moreover, unlike natural science experiments, it is impossible in the social sciences to control other variables. Not all political parties or candidates were the same when Lower House elections occurred in 1993 under the MMD system and when Lower House elections were held between 1996 and 2012 under the SMD system, and issues debated during these periods differed. We can therefore not speak of "all else being equal," and it would be impossible to conduct such a comparison in the social sciences even in the future.

Despite this, we wrote this paper to emphasize the need for political science analyses based on objective data and the compilation of facts one by one. Another expected contribution from this paper is that it reveals the limits of SMD system in Japan, and thereby invoking the necessity of contriving more developed form of electoral system to further increase the political satisfaction of people and their overall wellbeing.

Instead of appealing to such simple and impractical answer, we hereby argue that any effort to genuinely improve the wellbeing of Japanese citizens and those under the similar political conditions has to go beyond "the black and white" type of practice that merely chooses between SMD and MMD systems, and begin a new macrodiscourse in terms of democracy and its electoral system. Although we have not yet suggested specific models as a possible third way in this paper, we still believe that this paper is meaningful as a threshold of new arguments which would eventually overcome the limits of traditional wisdom and decisively contribute to the improvement of wellbeing of the people in democratic regimes.

Discourse without humility is merely a statement of opinion, and we hope the analyses contribute to efforts to ensure that political science research avoids such potential pitfalls. $^{13}$

\footnotetext{
13 This paper cites, with appropriate additions and revisions, Kobayashi, Yoshiaki. "Measuring the Effects of Political Reform: Changes and Continuity in Voting Behavior in Japan with the Introduction of the Single-Member and Proportional Representation System." Annual Political Science Review" Vol. I, 2005, 11-35; Kobayashi, Yoshiaki. A Japanese Democracy after Political Reform. Bokutakusha, 2008; Kobayashi, Yoshiaki. "Continuity and Changes in Voting Behavior" Report of the Japan Political Science Association, 2013; Yoshiaki Kobayashi, Yosuke Okada, Hidekuni Washida, and Kim Taehee. A Comparative Study of Representative Democracy. Keio University Press, 2014; and Kobayashi, Yoshiaki. Quantitative Analysis of Representative Democracy. Bokutakusha, 2017.
} 
Open Access This article is licensed under a Creative Commons Attribution 4.0 International License, which permits use, sharing, adaptation, distribution and reproduction in any medium or format, as long as you give appropriate credit to the original author(s) and the source, provide a link to the Creative Commons licence, and indicate if changes were made. The images or other third party material in this article are included in the article's Creative Commons licence, unless indicated otherwise in a credit line to the material. If material is not included in the article's Creative Commons licence and your intended use is not permitted by statutory regulation or exceeds the permitted use, you will need to obtain permission directly from the copyright holder. To view a copy of this licence, visit http://creativecommons.org/licen ses/by/4.0/.

\section{References}

Lijphart, A. (2012). Patterns of Democracy: Government Forms and Performance in Thirty-six Countries, Yale University Press, 1999, 2nd ed.

Chappell, Z. (2012). Deliberative Democracy A Critical Introduction. Palgrave.

Sandel, M. (2008) What's the Right Thing to Do? Farrar, Straus \& Giroux.

See, R. J. (2002). Justice as Rational Choice, in Justice Alternative Perspectives, James Sterba (ed.). Wadsworth Publishing Co.

Kobayashi, Y. (2012). Malfunctioning Democracy in Japan, Lexington Books.

Hinich, M. J., \& Ordeshook, P. C. (1970). "Plurality Maximization vs Vote Maximization: A Spatial Analysis with Variable Participation," American Political Science Review, Cambridge University Press, vol. 64(03), 772-91.

Dahl, R. A., \& Tufte, E. R. (1973). Size and Democracy. Stanford University Press.

Przeworski, A. (2000). Democracy and Development: Political Institutions and Well-being in the World, 1950-1990, Cambridge University Press.

Publisher's Note Springer Nature remains neutral with regard to jurisdictional claims in published maps and institutional affiliations. 